year, for a few cycles of sun-spots, the mineral conditions would be constantly varying; so that any test by the balance to compare the fruit of one year with that of another, would involve too many unappraisable elements to have a real value.

Prof. Jevons observes that his investigation is "embarrassed by the fact that no inquirer has been able to discover a clear beriodic variation in the price of corn." But the quality of periodic variation in more immediate effect of solar action than the price. Now, although perhaps not much is to be arrived at from the method suggested by Mr. Kemp, there is another direction in which something might be found, and in which the necessary data already exist. I allude to the records of those Corn Exchanges which contain full details of the measure-weight of every parcel of grain which has been sold in them for several sun-spot periods. I reduced the sales in the Haddington Corn Exchange for the year from July $3, \mathbf{1} 868$, to June 25 , 1869, and found the average bushel-weights as under:-

Wheat ... 27,764 quarters ..... 63.15 lbs. per bushel.

Barley ... 33,022 ", … 56.85 ," ,

Oats ...... 16,223 ", ..... $43^{\circ} 49$," ,

The sales in the Edinburgh Corn Exchange from November 4, a 868 , to October $27, \mathbf{1 8 6 9}$, gave the following weights:-

Wheat ... 27,322 quarters ..... 62.84 lbs. per bushel.

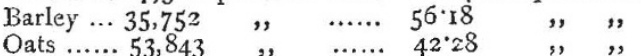

Reductions on this larger scale probably eliminate most of the elements of uncertainty. The measure-weight of the cereal grains depends on various factors, one of which is the comparative distension of the epicarp by the inclosed albumen. It is this element which may vary with variations of solar radiation. And if a cycle of measure-weight should te found corresponding with the sun-spot period, a clue might be gained to some unsuspected commercial relationship.

North Kinmundy, Aberdeen

A. Stephex WILsoN

\section{Time and Longitude}

I HAVE been much amused at the questions on the above (NATURE, vol. xviii. p. 40), by Mr. Latimer Clark, and the answer (p. 66) by my old friend Capt. J. P. Maclear; the numbers of NATURE for May having only just reached my "out-of-the-world" residence. I suspect Mr. L. C. has had in his mind what I have often had, and with which $I$ have frequently puzzled some "unco guid" Sabbatarians! If it is sucl a deadly sin to work on Sunday, one or the other of $A$ and $B$ coming, one from the east, the other from the west, of $180^{\circ}$ meridian, must, if he continues his daily avocations, be in a bad way! Some of our people in Fiji are in this unen. viable position, as the line of $180^{\circ}$ passes through Loma-Loma !

I went from Fiji to Tonga in H.M.S. Ny'mph, and arrived at our destination on Sunday, according to our reckoning from Fiji, but Monday, according to the proper computation west from Greenwich. We, however, found the natives all keeping Sunday. On my asking the missionaries about it they told me that the missions to that group and the "navigators," having all come from the castward, had determined to observe their seventh day, as usual, so as not to subject the natives to any future puzzle, and agreed to pat the dividing line further off, between them and Hawaii, somewhere in the broad ocean, where there were no metaphysical natives or "intelligent Zulus" to cross-question them!

British Consulate, Noumea, New Caledonia

\section{Hereditary Transmission}

I HAVE perused with interest Mr. Edmund Watt's account of the six-fingered family in Dominica, as it recalls to my memory a family showing precisely the same peculiarities in Ceylon, at Point Pedro, the most northerly point of the island, where, twenty-six years ago, I was magistrate.

A family quarrel came before me, and I found, to my great astonishment, that plaintiff and defendant, and all the witnesses, had six fingers on each hand and six toes on each foot! The additional finger or toe was, in each instance, a "little finger" (or toe) inserted in the side of the hand o: foot, quite loosely, adhering to the shin, and not part of the skeleton. It might easily have been excised with a pair of ordinary scissors. The parties were all closely related-brotbers and sisters, uncles and aunts, nephews, nieces, and cousins-they must have had a common progenitor. It would be essy, and most intcresting, to ascertain if any of the fanily now exist, an?, if so, if the supplementary finger has been transmitted to the present gene. ration. A note to the "Resident Magistrate," Point Pedro, would, I hope, produce a reply. If any of the family of my old clerk, Mr. Dehoedt, survive, they would recollect the fact. I think the party came from Panditerripu. E. L. LAYARD

British Consulate, Noumea

\section{"Survival of the Fittest"}

In NATURE, vol. xix. p. I55, Mr. S. F. Clarke's observations on the cannibal habits so rapidly developed by the larvæ of the New England salamanders are cited in illustration of the survival of the fittest. The fact that similar tendencies are invariably betrayed very early in life by theyoung of the common Mexican Axolotl (Siredon mexicanum), numbers of which are annually hatched out in the Brighton Aquarium, may perhaps be of interest. Many of the smaller and weaker ones are bodily devoured by their stronger brethren of the same brood, an inclina tion which is so marked that systematic over-feeding is resorted to in order to arrest the diminution in the number of specimens.

Brighton, December 27, 1878 A. CRANE

\section{Shakespeare's Colour-Names}

IN the very interesting articles and correspondence which you have published on the subject of colour-blindness, it is rathe: surprising that no one has referred to a passage which, if taken alone, would appear to show that Shakespeare did not know the difference between green and blue. In "Romeo and Juliet" (Act iii., Scene 5), the Nurse says to Juliet, speaking of Paris :"Oh, he's a lovely gentleman;

Romeo's a dish-clout to him; an eagle, madarn,

Hath not so green, so quick, so fair an eye

As Paris hath."

What is here called a green eye is evidently what we call a blue one. But Iago ("Othello," Act iii., Scene 3) calls jealousy a "green-eyed monster," using the expression "green-eyed" as a modern might use it, and meaning something very unlike "blue-eyed." These instances appear only to show that in the Ianguage of Shakespeare's time the names of colours were nsed somewhat vaguely. JOsEpH JOHN MURpHy

Old Forge, Dunmurry, co. Antrim, December 23

\section{DISCUSSION OF THE WORKING HYPOTHESIS THAT THE SO-CALLED ELEMENTS ARE} COMPOUND BODIES ${ }^{1}$

$\mathrm{T}^{\mathrm{T}}$ is known to many Fellows of the Society that $\mathrm{I}$ have

for the last four years been engaged upon the preparation of a map of the solar spectrum on a large scale, the work including a comparison of the Fraunhofer lines with those visible in the spectrum of the vapour of each of the metallic elements in the electric arc.

To give an idea of the thoroughness of the work, at all events in intention, I may state that the complete spectrum of the sun, on the scale of the working map, will be half a furlong long; that to map the metallic lines and purify the spectra in the manner which has already been described to the Society, more than 100,000 observations have been made and about two thousand photographs taken.

In some of these photographs we have vapours compared with the sun; in others vapours compared with each other; and others again have been taken to show which lines are long and which are short in the spectra.

I may state in way of reminder that the process of purification consisted in this: When, for instance, an impurity of manganese was searched for in iron, if the longest line of $\mathrm{Mn}$ was absent, the short lines must also be absent on the hypothesis that the elements are elementary; if the longest line were present, then the impurity was traced down to the shortest line present.

The Hypothesis that the Elements are Simple Bodies does not include all the Phenomena

The final reduction of the photographs of all the metallic elements in the region $39-40-$ a reduction I ${ }^{x}$ Paper reat at the Royal Sxiety, December $x z$, by J. Norman Lockjer, F.R.S. 